\title{
REPRESENTASI PERTENTANGAN KELAS DALAM PERTUNJUKAN LENG
}

\author{
Nissa Argarini \\ Wahyu Novianto \\ Institut Seni Indonesia Surakarta \\ nissagrarini94@gmail.com
}

\begin{abstract}
Abstrak: Pementasan Leng merepresentasikan struktur sosial masyarakat yang terbagi menjadi dua golongan, yaitu kaum pemilik modal dan kaum marginal. Pertunjukan Leng menguraikan rumusan masalah mengenai representasi pertentangan kelas sosial. Teori yang digunakan untuk menganalisis kelas sosial yaitu teori sosiologi seni Janet Wolff. Metode penelitian deskriptif analitik ini akan menggunakan data-data kualitatif yang diperoleh dari video dokumentasi pertunjukan Leng tahun 1986, sedangkan pengumpulan data yang digunakan adalah studi dokumentasi, pustaka, dan wawancara. Pertunjukan Leng merupakan representasi dari kelas sosial masyarakat Jawa, dan tokoh-tokoh yang dihadirkan oleh Kenthut mewakili kelas sosial yang diperjuangkan, yaitu wong cilik. Berawal dari kepekaan Kenthut terhadap masyarakatnya, memicu Kenthut dalam membuat karya Leng. Kepekaan Kenthut tercermin dalam konstruksi dramatik dan artistik pertunjukan Leng bahwa kelas sosial masyarakat Jawa erat kaitannya dengan kondisi sosial yang terjadi.
\end{abstract}

Kata-kata kunci: Kenthut, pertunjukan Leng, kelas sosial, priyayi, dan wong cilik.

\begin{abstract}
:
Leng represent the social structure of society which divided into two groups, namely the capital owners and the marginal society. Sociology theory of Janet Wolff was used to analyze the social class problems. This research is descriptive-analytic research using a qualitative method in which the data is obtained from the 1986 Leng performance video documentations, literature review, and interviews. The Leng performance is a representation of the social class of Javanese community, and the figures which presented by Kenthut represent the social class that is championed, namely the grassroots. Starting from Kenthut's sensitivity towards his community, triggered him in making the Leng. Kenthut's sensitivity is reflected in the dramatic and artistic construction of Leng that the social class of Javanese people is closely related to the social conditions that occur.
\end{abstract}

Key words: Kenthut, Leng, social class, priyayi, grass-roots society

\section{Pendahuluan}

Makam Kyai Bakal berada di Desa Bakalan. Suatu ketika, kekusyukan doa yang dilantunkan oleh juru kunci makam, Pak Rebo, mulai terusik dengan deru mesin pabrik. Suara mesin pabrik yang semakin memekakkan itu merupakan sebagian gangguan kecil. Bahaya yang lebih besarnya adalah rencana perluasan pabrik yang akan menggusur seluruh area di Desa Bakalan, termasuk makam Kyai Bakal. Bongkrek salah satu mantan mandor pabrik-merasa terusik dan sakit hati atas perlakuan pemilik pabrik. Bongkrek berniat nglurug dan melakukan perlawanan kepada Juragan. Tindakan Bongkrek membuat Bedor -tangan 
kanan Juragan - terpaksa menghabisi Bongkrek dengan menembaknya.

Sinopsis di atas merupakan sedikit gambaran pertunjukan lakon Leng oleh Teater Gapit. Lakon Leng karya Bambang Widaya Sp ini dipentaskan tahun 1986 di Sasono Mulyo Surakarta. Pertunjukan disutradarai langsung oleh Kenthut, panggilan akrab Bambang Widaya Sp. Leng ditulis sekitar tahun 1985 dengan mengangkat permasalahan yang terjadi pada masyarakat di sekitar Makam Kyai Bakal. Kenthut mampu menggambarkan kondisi masyarakat marginal yang terancam karena penguasa yang sewenang-wenang. Karya yang dihadirkan oleh Kenthut merupakan representasi dari realitas social (lihat Widaya, 1998).

Janet Wolff menyatakan bahwa seni adalah produk masyarakat karena seni adalah bentuk ungkapan perasaan dan pikiran masyarakat (Yudiaryani, 2015). Seni dan masyarakat sangat dekat hubungannya, karena struktur yang ada dalam masyarakat mampu menciptakan struktur dalam seni. Pada masa Orde Baru, struktur masyarakat tampak adanya kesenjangan sosial. Kekuatan penguasa yang dominan memberi pengaruh besar dalam segala bidang, tidak hanya terjadi dalam wilayah ekonomi dan politik, tetapi kesenian pun turut mendapatkan pengaruh yang kuat. Pihak-pihak yang sering mengkritik pemerintah atau menentang kebijakan pemerintah akan ditangkap. Kesenian pada masa Orde Baru banyak yang menggambarkan situasi di Indonesia. Salah satunya adalah naskah Leng yang ditulis oleh Kenthut. Kenthut mengolah apa yang dirasa, dilihat, maupun didengar menjadi sebuah karya yang dapat merepresentasikan masyarakatnya. Kenthut bukan hanya mengekspresikan masyarakat, melainkan juga mengungkapkan ekspresinya sendiri.

Kenthut merupakan anggota dari masyarakat yang mendapat pengaruh besar dari lingkungannya, yaitu lingkungan pada masa Orde Baru, saat rezim otoriter berkuasa. Kondisi sosial masyarakat pada masa itu lebih memihak kepada kaum pemilik modal, sehingga kaum marginal makin terpinggirkan. Kenthut merasakan betul sulitnya hidup pada masa Orde Baru. Kenyataan pahit yang harus dialami oleh Kenthut justru memancing imajinasinya untuk merespon kondisi sosial masyarakat di sekitarnya.

Pementasan Leng merepresentasi struktur sosial masyarakat yang terbagi menjadi dua golongan, yaitu kaum pemilik modal dan kaum marginal. Kaum pemilik modal dalam Leng diwakil oleh tokoh Juragan, sedangkan kaum marginal diwakil oleh tokoh Bongkrek. Kenthut hendak menghadirkan realitas sosial melalui pertentangan yang terjadi antara Juragan dan Bongkrek. Leng menghadirkan tokoh Juragan sebagai seorang yang memiliki kekuasaan atas wilayah Desa Bakalan. Bongkrek, salah satu tokoh yang mewakili masyarakat marginal (terpinggirkan karena terdesak pembangunan) hadir sebagai tokoh yang mengalami ketertindasan atas kekuasaan Juragan. Hal ini menjadi salah satu sumber pertentangan yang terjadi dalam pementasan Leng. Pertentangan berawal dari kesewenangan Juragan menguasai tanah warga Desa Bakalan tanpa memperhatikan kesejahteraan warga. Perlakuan Juragan atas tanah warga dan kesejahteraan warga yang diabaikan membuat Bongkrek geram dan memiliki niat untuk melakukan perlawanan.

Relasi pembentukan individu akibat dari kehidupan sosial, seperti halnya yang telah dipecahkan oleh Berger dan Luckmann (dalam Wolff, 1981) bahwa masyarakat terkonstruksi secara sejarah oleh orang atau sekelompok orang, dan orang itu juga terkonstruksi di dalam dan oleh masyarakat (melalui sosialisasi dan internalisasi). Kondisi ini yang dialami pula oleh Kenthut kemudian dituangkan dalam karyanya berjudul Leng. Kenthut memberikan reaksi 
atas kehidupan sosial yang dialami masyarakat. Leng hendak memproyeksikan kehidupan yang ada di sekitarnya. Kenthut berupaya untuk mengangkat keberadaan kaum pinggiran yang terancam penguasa. Dalam hal ini penguasa yang dimaksud adalah Juragan.

Pengalaman hidup yang bersinggungan dengan diri Kenthut menjadikan pematik kreativitasnya untuk berkarya. Dalam kondisinya merespon masyarakat, Kenthut menyoroti persoalan pertentangan kelas yang terjadi di dalamnya. Pertentangan kelas tersebut yang dituangkan dalam karya Leng. Kondisi sosial yang selalu terjadi dan meliputi kehidupan masyarakat dari desa, hingga kota. Persoalan pertentangan sosial menyebabkan berbagai masalah sosial. Permasalahan ini tidak habis untuk dibahas, dan memaksa untuk segera mendapatkan solusi. Dalam respon Kenthut lebih fokus pada lingkup masyarakat. Kelas sosial dalam masyarakat Jawa diklasifikasikan lebih kompleks. Permasalahan ini menjadi sorotan penting untuk dibahas, sehingga menarik untuk dilakukan penelitian lebih dalam.

\section{Kedudukan dan Status Sosial dalam Masyarakat Jawa}

Pada masyarakat Jawa kedudukan dan status sosial masih berlaku hingga kini terutama berdasarkan tingkat ekonominya. Kedudukan seseorang dapat dilihat dari kemampuan dalam mengendalikan, mempengaruhi, dan menguasai orang lain. Makin tinggi jabatan yang disandang, akan semakin besar kesempatan dalam menguasai sesuatu. Kedudukan seseorang yang berbeda jabatan sebagai salah satu penyebab terjadinya kelas sosial dalam masyarakat. Pada pembagian kelas masyarakat Jawa dikenal sebutan raja, priyayi, juragan, santri, abangan, wong cilik, dan sebagainya. Pembagian kelas itu ada yang berdasarkan keturunan, pekerjaan, kemampuan dalam bidang tertentu, atau atas jasa yang telah dilakukan.

Perbedaan tingkat ekonomi menjadi salah satu faktor timbulnya kelas-kelas sosial dalam masyarakat. Johnson (1986) menyetujui tentang adanya kontradiksi sosial yang terjadi dalam masyarakat dengan pembagian kerja dan pemilikan pribadi akan menimbulkan pertentangan antara kepentingan-kepentingan materiel dalam kelas-kelas sosial yang berbeda. Kontradiksi yang ada dalam masyarakat sering menimbulkan konflik sosial karena adanya perbedaan kelas. Pada masyarakat Jawa dikenal sebuatan keluarga ningrat, keluarga kerajaan, keluarga rakyat jelata, dan sebagainya. Sebutan itu mengklasifikasikan masyarakat Jawa dalam beberapa tingkatan kelas sosial. Geertz (1996) melihat masyarakat Jawa di Mojokuto sebagai suatu sistem sosial yang terdiri dari tiga subkebudayaan Jawa yaitu abangan, santri, dan priyayi. Berbeda dengan Geertz, Kuntowijoyo (2006) melihat masyarakat Jawa di Surakarta pada kurun waktu 1900 hingga 1915 dan mengklasifikasikan masyarakat menjadi raja, priyayi, dan kawula (lihat juga Kartodjirjo dkk, 1987). Dari beberapa pendapat yang telah disebutkan, dapat ditarik kesimpulan bahwa kelas sosial masyarakat Jawa diklasifikasikan sebagai priyayi dan wong cilik. Priyayi yang terdiri dari pejabat pemerintah, pengusaha, orangorang yang memiliki kekayaan, dan orangorang yang memiliki jabatan dalam profesi tertentu. Wong cilik terdiri dari masyarakat marginal, orang-orang yang berpendapatan rendah, dan tidak memiliki jabatan, maupun kekuasaan terhadap sesuatu.

\section{Priyayi dalam Masyarakat Jawa}

Priyayi mewakili tradisi yang agung sehingga akan terdapat sekumpulan kelompok sosial yang menjadi bawahannya. Adanya 'bawahan' bukan berarti terdapat hubungan kekuasaan yang mengikat, 
melainkan hubungan yang terjalin alami sebagai akibat dari sistem infrastruktur ekonomi seperti yang dikemukakan oleh Marx. Geertz (1996) menyampaikan bahwa kaum priyayi umumnya selalu berada di kota-kota, bahkan salah satu ciri Jawa modern yang secara sosiologis paling menarik adalah besarnya jumlah priyayi di kota-kota. Ada beberapa alasan hingga priyayi banyak yang tinggal di kota antara lain sebagai stabilitator politik dalam masa colonial, karena kehidupan di kota sangat kompleks, dan priyayi merasa lebih dihargai secara martabat maupun secara prestasi di samping keterampilan politik.

Dewasa ini, tentunya juga masih ada penggolongan masyarakat berdasarkan keturunan dari raja tetapi hal itu sudah tidak menyebar luas seperti pada masa kolonial. Kedudukan priyayi dengan rakyat membaur. Pembauran itu menipiskan jarak dan seakan menipiskan pula penggolongan kelas sosial. Saat ini penggolongan kelas sosial seseorang lebih condong pada takaran kepandaian dan kesuksesan dalam karier, pekerjaan, hingga pengaruh kekuasaan. Penggolongan itu memperjelas bahwa tingkat ekonomi menjadi takaran penting pengelompokkan seseorang tentang status dan kedudukannya dalam masyarakat. Priyayi dalam hal ini masih dapat dipertahankan sebagai golongan kelas sosial yang berlaku. Berdasarkan hal tersebut sebutan untuk priyayi dalam masyarakat Jawa dapat dipertahankan dengan penggolongan berdasarkan tingkat pendidikan, kedudukan dalam pekerjaan, ataupun berdasarkan kekuasaannya dalam hal ekonomi.

Masyarakat kelas atas yang memiliki kekuasaan atas masyarakat kecil digolongkan sebagai priyayi. Alasan penggolongan itu selain berdasar pendapat Geertz (1996) juga berdasarkan rumusan Van Niel mengenai kedudukan priyayi yang menguasai, memiliki daya untuk mengatur, dan sekaligus memberi pengaruh terhadap kelompok yang dikuasai. Hal ini dapat ditarik pada masa pemerintahan Orde Baru yang menjadikan para pemimpin memiliki hak penuh untuk menguasai masyarakat kecil. Dalam hal ini pemerintahan Orde Baru berstatus priyayi atas kedudukannya terhadap masyarakat Indonesia kurun waktu 1966 hingga 1998.

Pemerintah Orde Baru menggalakkan pembangunan besar-besaran di beberapa wilayah di Indonesia. Pengembangan pembangunan memanfaatkan relasi pejabat dengan para pengusaha swasta. Para pengusaha swasta berlomba untuk 'dekat' dengan pemerintah. Sudah menjadi rahasia umum apabila sebuah perusahaan atau industri yang berjalan tidak sesuai prosedur kemudian bekerja sama dengan oknum dengan memberi 'upah' sebagai 'penjaga' usahanya (Sawega, wawancara 30 Januari 2017). Kedekatan itu dilakukan sebagai salah satu cara untuk lebih mengembangkan bisnis mereka. Cara yang dilakukan oleh pengusaha ini sebagai kekuatan untuk mencari keuntungan lebih besar. Sawega mengiyakan hal itu, sebagai seorang jurnalis ia paham betul bagaimana kondisi sosial yang terjadi di Solo (khususnya) waktu itu.

Pemerintah Orde Baru memang menggalakkan pembangunan infrastruktur sebagai upaya memajukan kehidupan masyarakat Indonesia, tetapi pembangunan itu harus 'memakan' korban. Salah satu contoh pembangunan sistem irigasi di daerah Wonogiri pada waktu itu harus mengorbankan penduduk desa untuk rela menjadi peserta transmigrasi. Hal ini terjadi di beberapa daerah lain yang mengalami pembangunan demi kemajuan negara saat itu. Dampak yang dihasilkan dari kondisi sosial Indonesia saat itu tidak hanya pada pembangunan berupa fisik, tetapi dirasakan pula pada wilayah mental masyarakat. Dampak budaya, politik, ekonomi juga merasakan perubahan atas kebijakankebijakan 'kejam' masa Orde Baru. 
Masyarakat saat ini memandang pejabat pemerintahan, pengusaha, dan keturunan raja (yang masih ada) sebagai seorang priyayi. Walaupun masyarakat sekarang dapat membedakan mana yang seorang ningrat dan mana yang seorang penguasa (berdasarkan tingkat kekuasaan ekonominya). Kesimpulan itu berdasarkan tingkat ekonomi yang lebih tinggi dari masyarakat kebanyakan, pengaruh priyayi untuk mempengaruhi dan menguasai kelas sosial masyarakat lain. Kelas sosial priyayi yang mempertegas kedudukannya, secara alami akan membentuk kelas sosial lain dari kelompok masyarakat yang dikuasainya.

\section{Wong Cilik dalam Masyarakat Jawa}

Klasifikasi kelas sosial telah ada sejak zaman dahulu. Adanya priyayi tentunya juga akan ada masyarakat dengan kedudukan dan status sosial lebih rendah. Priyayi dianggap sebagai golongan masyarakat elit yang jumlahnya terbatas. Keterbatasan ini karena penggolongan priyayi yang hanya dari raja beserta keturunannya dan pejabat pemerintahan. Apabila golongan priyayi merupakan golongan yang terbatas, maka ada golongan lain yang lebih banyak jumlahnya. Golongan kebanyakan adalah golongan masyarakat yang tidak masuk daftar kualifikasi sebagai priyayi. Pada masa kolonial masyarakat kebanyakan disebut dengan kawula.

Pada masyarakat Jawa penyebutan golongan kelas sosial lebih pada tingkat ekonominya. Pada masa kolonial tidak semua rakyat dapat mengenyam pendidikan, pendidikan menjadi kurang merata di setiap kelas sosial. Hal itu menimbulkan perbedaan yang mencolok antara wong cilik yang tidak bersekolah dengan anak priyayi yang diberi kesempatan untuk mengenyam pendidikan, bahkan hingga Negeri Belanda. Perbedaan sistem pendidikan berdampak pada tingkat ekonomi masyarakat kebanyakan. Saat wong cilik tidak diberi kesempatan untuk bersekolah, maka tingkat ekonominya tidak akan berubah menjadi lebih baik. Pendidikan menjadi sangat penting sebagai tolak ukur kesuksesan seseorang membawa diri. Lain ceritanya apabila ada seorang wedana atau pejabat pemerintahan lain yang mengangkat anak dari selirnya untuk mendapatkan kesempatan menjadi seorang priyayi. Hal itu akan mengubah dunia sekitarnya untuk menghormati seseorang yang telah menjadi priyayi. Ada juga seorang dari masyarakat kebanyakan 'magang' pada seorang priyayi selama beberapa tahun, ia akan mendapat kesempatan untuk menjadi seorang priyayi pula atas pengabdiannya.

Status sosial wong cilik dalam masyarakat Jawa secara ekonomi berada dalam kondisi menengah ke bawah. Ketidakberuntungan wong cilik dalam pemenuhan kebutuhan mengakibatkan kurangnya kesadaran terhadap kesehatan, pendidikan, tempat tinggal yang layak, dan berbagai masalah kehidupan lain. Klasifikasi kelas ini tidak terlepas dari hubungan yang terjalin antarkelas yang berkuasa dan menguasai.

Pada masa pemerintahan Orde Baru, pemerintah melakukan pembangunan infrastruktur secara besar-besaran. Teguh Pranoto menyebutkan bahwa rezim Orde Baru demikian kuat, semangat industrialisasi meluap-luap dan masuk ke desa-desa tanpa mempertimbangkan tatanan dan nilai-nilai tradisi serta kehidupan masyarakat (dalam Feinsten, 1995). Masyarakat yang disebut Pranoto lebih mengarah pada masyarakat yang lemah kekuasaan, tinggal di desa, dan masih memegang teguh nilai tradisi. Masyarakat itu masuk dalam golongan kelas wong cilik, karena teridentifikasi sebagai masyarakat dengan tingkat ekonomi menengah ke bawah.

Penggolongan masyarakat sebenarnya tidak hanya berdasarkan tingkat ekonomi. Kartodirdjo (1987) menyebutkan klasifikasi sosial masyarakat dapat dilihat menurut 
dimensi sosial, dimensi politik, dan dimenasi ekonomi. Merujuk pada teori Marxisme yang terus-menerus menekankan bahwa struktur ekonomi menjadi hal yang dasar untuk melihat kehidupan kelas sosial masyarakat. Pemahaman Marx terhadap kelas sosial menempatkan dimensi ekonomi paling mencolok, menjadikan infrastruktur ekonomi menjadi dasar superstruktur dari sosiobudaya. Kehidupan sosial dan budaya masyarakat merupakan dampak dari adanya perubahan infrastruktur ekonomi yang sedang dialami dalam suatu pemerintahan negara.

Rezim Orde Baru gencar melakukan pembangunan infrastruktur, tetapi pembangunan itu belum mampu merata hingga di wilayah pinggiran karena pembangunan masih terpusat pada wilayah tertentu. Pembangunan masa itu memang menyelesaikan satu masalah, tetapi juga menghadirkan masalah baru. Ketidakmerataan pembangunan tentu berdampak pada masyarakat. Jika masyarakat tinggal di daerah pusat pembangunan, tentu akan mendapat dampak positif mulai dari kemudahan akses transportasi hingga kemudahan sistem ekonomi. Pertanyaannya, bagaimana nasib masyarakat yang jauh dari pusat pembangunan? Hal tersebut dapat langsung dijawab bahwa kondisi masyarakat itu terpinggirkan, atau disebut dengan masyarakat marginal. Masyarakat marginal adalah masyarakat yang berada dalam suatu wilayah yang kurang mengalami pesatnya pembangunan infrastruktur sebagai upaya pemerintah untuk memanjukan negara.

Masyarakat marginal ini masuk dalam penggolongan kelas sebagai wong cilik, merujuk pada pengertian sebelumnya bahwa kedudukan wong cilik di Jawa merupakan masyarakat yang memperoleh pengaruh dari penguasa, tingkat ekonomi mereka lemah, dan berpendidikan lebih rendah dari yang menguasainya. Kondisi tersebut menyebabkan masyarakat kebanyakan ini secara terpaksa menerima untuk dikuasai dan menjadi kelompok sosial yang kalah.

\section{Kesenjangan Sosial antara Priyayi dan Wong Cilik}

Kelas sosial priyayi dan wong cilik dalam masyarakat Jawa merupakan suatu hubungan saling terkait satu sama lain. Hubungan kedua kelas sosial ini disebabkan oleh beberapa faktor seperti faktor ekonomi, politik, dan sosial. Hadirnya dua kelas sosial ini bukan tidak mungkin akan menyebabkan kesenjangan sosial. Kesenjangan sosial terjadi karena ketidakmerataan akses terhadap sumber ekonomis yang dimiliki (Dewanta dkk, 1995). Ketidakmerataan tersebut adalah dampak pembangunan yang dilakukan pemerintah hanya berpusat pada suatu wilayah, sedangkan wilayah lain yang jauh dari pusat pembangunan kurang dapat merasakan dampak positifnya. Pembangunan yang digalakkan oleh pemerintah sebenarnya merupakan cara untuk menarik simpati masyarakat secara politik, walaupun tujuan lainnya memang untuk memajukan negara. Kenyataan tersebut berdampak pada kehidupan perekonomian masyarakat, yang dekat dengan infrastruktur baru akan dimudahkan untuk meningkatkan ekonomi, sedangkan yang jauh akan semakin mengalami kemunduran tingkat ekonomi.

Perubahan pada beberapa bidang kehidupan masyarakat tersebut secara otomatis akan berdampak pada kehidupan sosial. Kesenjangan sosial akan makin tebal di antara yang kaya dan yang miskin. Telah disimpulkan bahwa masyarakat dalam kondisi terpinggirkan, dikuasai, rendah ekonomi, rendah pendidikan merupakan ciri kelas wong cilik dalam klasifikasi kelas di Jawa. Masyarakat yang memiliki kuasa atas masyarakat lain, berpendidikan tinggi, dan memiliki pengaruh cukup kuat merupakan kelas priyayi. Kesenjangan yang terjadi antara priyayi dan wong cilik akan terjadi 
seiring bertahannya ketidakmerataan dalam sistem tata kehidupan masyarakat.

Pada rezim Orde baru, para pengusaha yang dalam masyarakat Jawa disebut sebagai priyayi itu sering bekerja sama dengan pejabat pemerintahan. Hal itu dilakukan untuk memberikan penawaran kerja sama dengan alasan demi kemajuan pembangunan negara. Priyayi-priyayi memanfaatkan kedekatan tersebut untuk berekspansi ke daerah untuk meluaskan wilayah kekuasaannya. Kebijakan priyayi sudah tentu dengan melibatkan pejabat pemerintahan sebagai 'pagar pengaman'. Tindakan yang dilakukan oleh pengusaha ini sebenarnya memberikan kesempatan bagi masyarakat kecil untuk turut serta memajukan diri dan memperbaiki kehidupan. Keinginan masyarakat kecil kadang kala harus tertahan dan bahkan harus terhenti, ketika pihak pengusaha tidak memberikan kesempatan untuk menjadi jembatan kemajuan masyarakat di wilayah tempat mendirikan usaha. Hal ini menjadikan kedudukan dan status dari para priyayi dianggap tidak memberi kesejahteraan bagi wong cilik. Kondisi tersebut menyebabkan kesenjangan terus terjadi hingga kini.

Wong cilik pada masyarakat Jawa masih menanamkan rasa 'sungkan' untuk melawan priyayi yang menguasainya. Perilaku wong cilik seperti itu merupakan sebuah kesadaran atas kelas yang membedakan mereka dengan priyayi. Kondisi legawa yang dialami oleh sebagian wong cilik ini yang kemudian dimanfaatkan oleh priyayi-priyayi untuk mengeruk keuntungan. Kenyataan yang sering muncul saat terjadi perbedaan kelas, hingga berujung konflik, disebabkan oleh perbedaan kepentingan dan rasa ingin memenuhi kebutuhan hidup masing-masing. Sebagian wong cilik menerima perlakuan priyayi yang semena-mena, tetapi ada sebagaian wong cilik lain yang melawan kondisi tersebut.
Konflik yang timbul karena perbedaan kelas merupakan dampak dari kondisi kesenjangan sosial yang dihadapi oleh masyarakat. Kesenjangan antar kelas sosial disebabkan oleh ketidakmerataan pembagian nilai tambah (Dewanta dkk, 1995). Kelas, bagi Marx, selalu didefinisikan sebagai sesuatu yang berpotensi menimbulkan konflik (Ritzer \& Goodman, 2014). Konflik kelas sosial antara priyayi dan wong cilik dalam masa pemerintahan Orde Baru menyebabkan kondisi sosial wong cilik makin terpojok, sedangkan priyayi semakin kaya. Inilah yang dinamakan kondisi kesenjangan sosial sebagai dampak dari adanya sistem kelas sosial yang makin mencolok.

\section{Pertentangan Kelas Masyarakat dalam Pertunjukan Leng}

Seniman adalah anggota masyarakat yang melihat dan memahami kondisi sosial dari masyarakatnya. Seniman melakukan pembacaan terhadap masyarakatnya, hasil bacaan tersebut menghasilkan karya seni. Kenthut juga melakukan pembacaan terhadap masyarakat di sekitarnya.

Kenthut, melalui pertunjukan Leng mengajak penonton, pembaca, dan penikmat seni untuk sadar bahwa dalam dunia ini ada mikrokosmos dan makrokosmos yang membungkus kehidupan. Bagi mistikus Jawa, makrokosmos tampil sebagai sebuah paradigma bagi mikrokosmos yaitu manusia (Mulder, 2001). Kenthut menggiring penonton untuk memahami bahwa sebenarnya pertentangan hadir dari diri sendiri. Manusia menghadirkan emosi, hasrat, dan gairah untuk mendapatkan sesuatu yang belum dimiliki. Saat seseorang tidak mampu mengendalikan emosi, hasrat, maupun gairahnya, maka akan terjadi singgungan negatif dengan manusia lain, bahkan akan terjadi konflik dengan masyarakat lain. Ada beberapa faktor yang menyebabkan seseorang dapat terlibat 
konflik, salah satunya adalah perbedaan kelas.

Pada pertunjukan Leng, Kenthut memperlihatkan bahwa adanya hubungan yang terjalin antara mikrokosmos dan makrokosmos dalam masyarakat Jawa. Pembahasan dalam bab ini akan menitikberatkan mengenai jalinan yang terkait dengan hubungan antara kehidupan warga Desa Bakalan dan kehadiran pabrik milik Juragan. Hubungan ini merupakan representasi Kenthut dalam melihat masyarakat di sekitarnya. Kenthut menegaskan bahwa jalinan hubungan mikro dan makro memberikan dampak di segala lini kehidupan masyarakat.

Hubungan mikrokosmos dan makrokosmos dalam pertunjukan Leng diwakili oleh keberadaan Bongkrek (warga Bakalan) dan makam Kyai Bakal yang dikeramatkan. Bongkrek dan warga Bakalan yang lain masih percaya akan magi dari makam Kyai Bakal. Mereka kerap melakukan ritual caos dhahar dengan membawa bunga setaman dan sesaji lain ke makam Kyai Bakal untuk berdoa. Juragan juga menunjukkan sikap hubungan makrokosmos dan mikrokosmos. Pada waktu tertentu, Juragan menyiapakan sesaji khusus dan bunga setaman untuk ritual menghormati nenek moyang atau déwa-dewané sing nunggu (disebutkan dalam dialog).

Jakob Sumardjo menegaskan bahwa seniman mampu melihat aspek realitas di balik kenyataan permukaan setiap peristiwa (Sumardjo, 2000). Lingkungan yang bersinggungan dengan Kenthut akan terlihat melalui pembacaan dalam pertunjukan Leng. Hal tersebut terjadi karena adanya relasi yang terjalin dalam konstruksi dramatik dan konstruksi artistik pertunjukan lakon Leng, kemudian akan menyiratkan pertentangan

\footnotetext{
${ }^{1}$ Kungkum dalam bahasa Indonesia berarti berendam. Dalam tradisi Jawa, istilah kungkum identik dengan 'laku' (Trisno Santoso,
}

antara kelas sosial yang digambarkan Kenthut.

\section{Hubungan Juragan dengan Bongkrek}

Perbedaan tingkat ekonomi di wilayah Bakalan telah menghasilkan sebuah perubahan tata kehidupan yang sudah ada sejak lama. Perbedaan tersebut memisahkan antara yang berkuasa diwakili oleh Juragan dan yang dikuasai diwakili oleh Bongkrek. Penggolongan kelas atas kuasa tersebut bermula karena pengaruh dari hadirnya pabrik milik Juragan yang membagi masyarakat Bakalan menjadi buruh dan pemilik modal. Pada pembahasan sebelumnya telah dipilah kelas sosial priyayi dan wong cilik. Juragan sebagai priyayi memiliki kekuasaan di atas warga Desa Bakalan. Terbukti bahwa kehadiran pabrik milik Juragan, kehidupan warga desa seperti telah bergantung pada pabrik.

Bongkrek adalah seorang warga Desa Bakalan yang pengangguran. Dia sudah berkeluarga tetapi kondisi rumah tangganya sedang tidak harmonis. Bongkrek belum juga mendapatkan pekerjaan baru, sedangkan anaknya dalam keadaan sakit. Pada kondisi tersebut, Bongkrek memilih untuk pergi ke makam Kyai Bakal. Makam tersebut dikeramatkan oleh warga sekitar, tak jarang juga tamu berdatangan dari luar desa. Tamu yang datang beragam dari yang bukan siapasiapa, hingga seorang pejabat pemerintahan dalam pertunjukan disebut wong Jakarta. Bongkrek merasa kedatangannya ke makam Kyai Bakal sebagai upaya untuk menenangkan batin, dan mencari solusi. Bongkrek dan waraga desa lainnya sangat percaya bahwa 'berkah' dari bersamadi di makam Kyai Bakal akan memberikan pencerahan hidup. Pada adegan kelima, Bongkrek pamit untuk pergi ke sungai, melakukan kungkum ${ }^{l}$ untuk bersamadi.

wawancara 12 Maret 2017). Laku sendiri merupakan salah satu usaha yang dilakukan seseorang untuk mendapatkan ilmu gaib, 
Berbagai cara dilakukan untuk mendapatkan wahyu dan ketenangan batin hingga permasalahan dalam hidup segera selesai.

Dendam Bongkrek pada pabrik dan Juragan telah menumpuk, hingga ia melalaikan prinsip dan sikap hidup sebagai orang Jawa. Orang Jawa memegang prinsip nrima ing pandum, pepatah yang mengarah pada persoalan toleransi, nrima dan legawa akan segala hal dalam hidup. Mereka menerima segala takdir hidupnya termasuk dengan hegemoni yang mungkin mereka alami. Pada suatu titik kehidupan, orang Jawa mungkin saja melalaikan sikap toleransi, nrima, dan legawa itu. Benar jika masyarakat Jawa tidak banyak menuntut, tetapi jika memutus lumbung ekonomi mereka sudah tentu akan terjadi pergolakan. Memutus lumbung ekonomi berarti cepat atau lambat juga akan memutus kehidupan. Kemarahan Bongkrek makin menjadi karena Yatmi -istri Bongkrek - memintanya untuk menjual tanah warisan guna biaya pengobatan anak bungsu mereka. Bongkrek menolak karena Yatmi berniat menjual kepada Juragan pemilik pabrik yang telah memecatnya dan warga desa lain. Kemarahan Bongkrek mencapai puncak. Bongkrek nglurug ke pabrik untuk membalas dendam pada Juragan, tetapi Bongkrek tertangkap dan ditembak oleh anak buah Juragan.

Persoalan tanah warisan ini dipertegas oleh Bongkrek, bahwa apa pun kondisi yang sedang dialami tidak akan menyerahkan secuil pun untuk dijual apalagi kepada Juragan pemilik pabrik. Sikap tegas Bongkrek tersebut seperti terlihat pada dialog di bawah ini:

PAK REBO : É, kosik, Krék! Lha pekarangamu sing ana pabrik rak ora arèp mbok ulungké ta?

BONGKREK : Dak tohi nyawa no. mBok arepa wong pabrik

kekuatan magi, atau untuk pesugihan. Ada pula yang melakukan kungkum hanya semata untuk menjalankan ritual ketenangan batin. nggunakaké punggawa kelurahan tekan kabupatèn pisan ta, aja manèh sak pekarangan, sak cuil eri baé ora arèp dak sorohkè.

KECIK : (MELU NYENGENI) Pak Rebo, mbok ampun gojegan.

PAK REBO : Sapa sing gojeg? Dhengkulmu amoh kuwi. Bongkrèk saiki rak wis lunga ta?

MBOK SENIK : Uwis ?!?

PAK REBO : Ya wis! Pokoké Bongkrèk dislametké dhisik, nyingkir. Kon ngungsi sing adoh pisan. Barang titipane rak wis digawa kabèh ta? (NILIKI BARANG SIMPENANE BONGKREK) Tenan. Uwis digawa kabèh. Kerisé Kyai Bugel piyandelé, karo cekelan liyané wis digegem. Sokur-sokur yèn Bongkrèk gelem nyingkir sedhéla nyang Sumantrah apa mBornéo.

KECIK : Nyingkir apane? (MENENG SEDHÉLA, UNJAL AMBEGAN) Kang Bongkrèk saiki malah nglurug marani mrana. Ora trima lemahé dikangkangi wong liya, uga patiné ragilé. Kétoké arèp ngamuk, mbales ngawur sak kecekelé. Toh nyawa, toh pati. Rasané wis kaya ora sabaéné, kaya dudu kang Bongkrèk biyén.

Seperti pepatah Jawa, sadumuk bathuk sanyari bumi, bahwa kehormatan bagi orang Jawa sangatlah penting bahkan akan dibela dengan nyawa bila perlu. Keputusan Bongkrek untuk nglurug pabrik salah satunya adalah untuk membela kehormatannya sebagai orang Jawa.

Leng menjadi gambaran Kenthut terhadap Indonesia masa Orde Baru. Pada masa Orde Baru sistem pemerintahannya 
otoriter, maka kritik sosial dan perbedaan cenderung dibungkam oleh penguasa (Sahid, 2000). Pada masa itu, banyak sekali mahasiswa bahkan seniman dibatasi ruang geraknya agar tidak melakukan banyak kritik terhadap pemerintah. Semua kehendak penguasa akan selalu disiapkan karpet merah agar lancar sesuai yang diinginkan. Perintah berasal dari satu pintu yaitu dari atas ke bawah, sehingga menyempitkan inisiatif warga negara untuk memajukan bangsa.

Juragan dalam pertunjukan Leng tidak jauh berbeda dengan Orde Baru itu sendiri. Ia memperlakukan semua anak buahnya seperti pesuruh. Semua harus mematuhi perintah yang diberikan oleh Juragan. Apabila terdapat sekali saja kesalahan, pemecatan menjadi jalan akhirnya. Juragan merasa punya kuasa penuh atas anak buahnya, sehingga dapat berlaku semena-mena. Kekuasaan otoriter Juragan diperlihatkan melalui dialog sebagai berikut:

JURAGAN : Nyambut gawé sembrana kabèh, ora ngati-ati. Nyekel barang rumit barang rumpil ki ora gampang, kelépyan sithik nyawané wong sak pabrik ilang. Yèn nganti kedadéyan tenan sapa menèh sing bakal gelem ketuding? Kaya iki, nyawané Bagong ora bakal bali merga padha nyepèlèkake. Dor sapa sing jaga dhisel?

BEDOR : Gombloh.

JURAGAN : Saiki pecat!

BEDOR : Mantèn anyar niku?

JURAGAN : Ora peduli. Pokoké dipecat!

BEDOR : . . . . ?

JURAGAN : Cepet. Saiki dipecat, goblog!

BEDOR : Nggih juragan. (BALIK KANAN MBENGOK) Mbloh. . . ! Sésuk kowé ora sah mlebu. Kowé dipecat.

\begin{abstract}
JURAGAN : Dor, mréné! Sing momong Bagong sapa?

BEDOR : Tomblok.

JURAGAN : Pecat!

BEDOR: Adhuh Ndhuk, bejamu. Pincukmu ditumplak. Urip ana kempitan kèlèk yèn kurang bejané mambu kecut isih gampang dijabut. Gèk sapa manèh ki sing kena walat? Dhasaré mung kawula alit, tekan rong puluh turunan dhapukané ya mung tetep kawula.
\end{abstract}

Rangkaian dialog di atas menunjukkan, bahwa Juragan memiliki keabsolutan kekuasaan. Sikap yang sewenang-wenang tidak hanya dialami oleh penjaga malam, tetapi sebagian besar karyawan pabrik yang berasal dari Desa Bakalan juga merasakan hal tersebut. Kekuasaan Juragan menjadi simbol kekuasaan Orde Baru, individu harus tunduk pada negara (Mulder, 2001). Saat Juragan hendak mengumpulkan keuntungan sebanyak-banyaknya, maka ia akan melakukan banyak cara untuk memperlancar usahanya. Juragan atau penguasa Orde Baru memberi kemudahan bagi para pengusaha dalam bisnis jika ada 'amplop' sebagai pelicinnya.

Pada pertunjukan Leng, Juragan mengklaim bahwa perluasan wilayah pabrik juga memperhatikan kesejahteraan warga desa, tentu juga kelangsungan makam Kyai Bakal. Pada praktiknya pembatasan bagi warga untuk sowan ke makam sangat merugikan. Juragan lebih memihak kepada tamu-tamu yang datang dengan membawa 'amplop' untuk sowan Kyai Bakal lebih dahulu. Ketidakadilan Juragan ini sematamata memuaskan nafsunya mengeruk keuntungan untuk kantongnya sendiri. Demi melancarkan usaha-usahanya, Juragan akan 'menghilangkan' siapa saja yang ingin menghalangi. Hal itu tampak pada dialog berikut: 
BEDOR : Hah. .. ? Ndara. Juragan. . Juragané. . . ! (MBISIKI JURAGAN) Bongkrèk juragané. Bongkrèk!

JURAGAN : Bongkrèk sapa?

BEDOR: Mandhor sing dipecat ndhisik. Ngancam Juragané.

JURAGAN : Goblog! Kok ora ndang dirampungi! Kawit ndhisik rak wis dak perintah ta? Lempung kabèh! Ndang dirampungi! Wedhus siji kaé mung dadi slilit yèn ora ndang disingkirke.

BEDOR : (WEDI) Nggih Juragané. . .

Penggalan dialog tersebut mengungkapkan bahwa Juragan akan bertindak tegas kepada siapa pun yang menghalangi usahanya, bahkan ia tega 'menghilangkan' Parno dan Kabul mantan pegawai pabrik yang juga warga Desa Bakalan. Tindakan Juragan untuk 'menghilangkan' orang-orang yang dianggap mengganggu ini sama dengan yang dilakukan oleh penguasa Orde Baru. Seperti yang telah terjadi pada salah satu aktivis asal Solo, Wiji Tukul, ia juga menghilang semenjak tragedi pelengseran pemerintahan Presiden Soeharto karena berani mengkritik kebijakan Orde Baru.

Kuasa Juragan terhadap beberapa orang anak buahnya menjadikannya lebih kuat. Seperti pada masa Orde Baru kekuasaan sepenuhnya berada di tangan Presiden Soeharto. Soeharto memegang kendali penuh terhadap stabilitas kehidupan masyarakat Indonesia di berbagai bidang. Dampak tersebut terasa hingga ke daerah-daerah termasuk Kota Solo, tempat di mana Kenthut membaca dan merepresentasikan kehidupan masyarakat. Kehidupan masyarakat Indonesia menurut Kenthut mampu terwakili oleh sudut pandang Jawa, sehingga ia merasa bahwa bahasa Jawa mampu menampung keluhan masyarakat Indonesia pada waktu itu.

Dalam masyarakat Jawa, wong cilik memandang priyayi sebagai panutan, center of interest untuk berkehidupan. Pandangan tersebut menjadikan wong cilik mudah untuk dipengaruhi, dikuasai, hingga diadu domba semata-mata demi keuntungan priyayi. Priyayi memandang wong cilik sebagai alat untuk meningkatkan pengaruh, kekuasaan, dan lahan keuntungan dengan mengambil hak-haknya. Ketidaksadaran akan hal tersebut secara otomatis menguatkan kondisi kesenjangan sosial di antara wong cilik dan priyayi. Dalam pertunjukan Leng direpresentasikan oleh Bongkrek dan Juragan. Kenyataan tersebut digambarkan oleh Kenthut pada persoalan sebagian warga Bakalan menerima dengan legawa hadirnya pabrik di tengah-tengah kehidupan mereka. Walaupun sebenarnya banyak dampak negatif yang ditimbulkan oleh pabrik. Sebagaimana sikap legawa yang juga ditunjukkan oleh masyarakat Wonogiri merelakan tanahnya untuk dibuat DAM. Sikap legawa ini sejalan dengan konsep hegemoni.

Hegemoni merupakan sebuah kepemimimpinan yang dipegang oleh kekuasaan dominan terhadap yang subordinat. Kepemimpinan ini dicapai bukan melalui cara-cara kekerasan dan dalam lingkungan masyarakat politik, melainkan melalui kesepakatan dan bekerja dalam lingkungan masyarakat sipil. Kesepakatan itu sendiri terbentuk sebagai hasil negosiasi terbatas antara kekuasaan dominan dengan masyarakat subordinat (Faruk, 2007).

Kekuasaan yang dominan tersebut tentu tergambar dalam diri Juragan atau pemerintahan Orde Baru. Pihak subordinat terwakili oleh Bongkrek, dan warga Desa Bakalan, juga warga-warga korban penggusuran oleh pemerintah, seperti yang dialami oleh masyarakat di Wonogiri. 


\section{Hubungan Antara Pabrik dan Makam Kyai Bakal}

Masyarakat Jawa mengenal istilah makro kosmos dan mikrokosmos yaitu hubungan yang terjalin antara manusia dan 'sesuatu yang berkuasa' di luar dirinya. Manusia dan tatanan kosmis saling berkaitan, bagian dari suatu keseluruhan dan jika manusia berjuang mencapai kesatuan dan keseimbangan, maka kehidupan akan menjadi lebih baik dan tentram (Mulder, 2001).

Pada lakon Leng, Kenthut menggambarkan kondisi masyarakat yang meyakini tentang hubungan dengan kosmisnya. Bongkrek yang mendapatkan permasalahan bertubi-tubi menjadikan makam Kyai Bakal sebagai tempat terakhir untuk mengadu, menjernihkan pikiran berharap mendapatkan wangsit berkah dari Kyai Bakal. Bongkrek masih percaya bahwa dengan ia bersamadi di makam, kungkum di sungai maka pencerahan atas permasalahannya akan segera terbuka. Keyakinan Bongkrek tentang magi dari sebuah makam leluhur adalah cerminan masyarakat Jawa warisan dari nenek moyang saat masih berkeyakinan animisme dan dinamisme. Bongkrek sebagai orang Jawa meyakini kekuatan magi alam raya lebih besar mengepung kehidupan manusia.

Praktik ritual itu tidak hanya dilakukan oleh Bongkrek, tetapi juga Juragan. Juragan sebagai orang modern juga melakukan praktik-praktik ritual. Pada beberapa kesempatan dan waktu tertentu Juragan menyiapkan sajèn khusus untuk 'dipersembahkan' pada 'yang dianggap sebagai penunggu'. Tindakan Juragan tentang kebiasaannya menyiapkan sajèn tersebut memperlihatkan bahwa praktik mistisisme bukan hanya terbatas pada wong cilik, melainkan kaum intelektual menengah, militer, bahkan hingga kaum elit tertentu (Mulder, 2001). Kebiasaan tersebut masih terus melekat, karena kesadaran kaum priyayi bahwa selama ini keselaran kehidupan juga berkat hubungan baik dengan 'yang memiliki kuasa lebih'. Juragan menjadi simbol manusia modern yang telah memberi jarak terhadap dunia mitis.

Kehidupan Juragan belum sepenuhnya terlepas dan meninggalkan kebiasaan melakukan ritual magi, sikap ini dalam pandangan Peursen (1976) disebut ontologis. Dalam dunia ontologis manusia mulai mengambil jarak terhadap segala sesuatu yang mengitarinya. Manusia mulai mempelajari praktis mengenai ilmu pengetahuan sebagai pembebas dari dunia mitis. Dalam perjalanan mempelajari ilmu pengetahun, sampailah manusia pada titik mempertanyakan adanya Tuhan. Pada tahap ini manusia ontologis bersinggungan kembali dengan dunia mitis untuk mempercayai adanya Tuhan sebagai pemegang kekuasaan tertinggi. Keadaan sama yang dialami oleh Juragan, di satu sisi dia telah menjadi manusia modern dengan kepercayaan pada kemajuan ilmu pengetahuan, dan di sisi lain Juragan masih melakukan praktik mitis (menyiapkan sesaji pada waktu tertentu).

Pada masa Orde Baru, Soeharto juga menunjukkan bahwa ia seorang ontologis seperti Juragan, walaupun terungkap setelah selesai masa jabatannya. Rezim Orde Baru mengidentikan diri dengan Rezim Budaya dengan titik tumpu menjaga tradisi. Soeharto sendiri sebagai pendiri rezim Orde Baru diyakini kuat menjalankan ajaran leluhur dengan melakukan ritual tertentu untuk menyerap dan mempertahankan kekuasaan. Soeharto secara pribadi juga nglakoni seperti menjalankan puasa dalam masa-masa tertentu, mengadakan upacara slametan dan mengujungi makam-makam atau petilasan kermat tokoh-tokoh besar di masa lampau (Bahaudin, 2015).

Soeharto diyakini sebagai penganut kejawèn yang meresapi dan memaknai betul ajaran kebatinan. Ajaran tersebut digunakan Soeharto sebagai sarana untuk memberi 
ketenangan bagi jiwanya, bahwa kepemimpinan masa Orde Baru bukan hanya menggunakan logos, melainkan juga dengan laku spiritual.

Van Peursen (1976) menyebutkan ada tiga tahap yang menunjukkan kecenderungan manusia menyikapi kebudayaan yaitu tahap mitis, tahap ontologis, dan tahap fungsionil. Berbeda dengan alam pikir ontologis, tahap mitis memposisikan diri sebagai seorang yang tidak dapat mengambil jarak terhadap suatu hal yang 'ajaib'. Anggapan manusia menurut Van Peursen mengenai suatu hal yang 'ajaib' seperti halnya warga Bakalan menganggap makam Kyai Bakal sebagai suatu tempat keramat. Bongkrek dalam hal ini menjadi simbol warga Bakalan sebagai manusia mitis.

Dilihat dari perspektif kosmologis, semuanya berhubungan, tidak dalam cara yang sembarangan, melainkan sebagai suatu keseluruhan teratur yang tunduk pada takdir dan bukan pada kemauan sendiri (Mulder, 2001). Konsep hidup orang Jawa tentang pentingnya hubungan harmonis antara manusia dengan manusia, manusia dengan alam semesta, dan manusia dengan Tuhan Yang Maha Esa (Pranoto, 2008). Masyarakat Jawa yakin bahwa ketika manusia berusaha untuk menyeimbangkan diri dengan kosmisnya, maka stabilitas kehidupan akan terjaga. Hal tersebut yang mendasari tindakan Bongkrek melawan Juragan. Ketidakseimbangan yang dianggap Bongkrek dilakukan oleh Juragan mengusik kesejahteraan Desa Bakalan, merusak kehormatan makam Kyai Bakal sehingga sudah patut untuk dilawan. Makam adalah tempat keramat tidak seharusnya diusik demi proyek perluasan pabrik. Makam sebagai simbol masyarakat Jawa bahwa segala yang ada saling berkaitan walaupun dengan leluhur yang telah meninggal sekalipun.

Makam Kyai Bakal dianggap masyarakat sebagai salah satu tempat yang sakral. Makam menjadi tempat untuk mencari ketenangan, mencari wangsit, dan juga dianggap sebagai jalan pintas menyelesaikan suatu permasalahan hidup. Pak Rebo, Mbok Senik, Kecik, Bongkrek, dan Janaka adalah representasi masyarakat Jawa yang menganggap bahwa makam menjadi tempat yang tepat untuk ngalap berkah. Banyak cara orang Jawa bertirakat untuk menyelaraskan kosmosnya, seperti nenepi, kungkum di sungai, atau memberi sesaji pada makam leluhur. Pak Rebo, Mbok Senik, Kecik, Bongkrek, dan Janaka sebagai wong cilik melantarkan doa-doa untuk leluhur di makam Kyai Bakal. Kegiatan ini pada pemikiran modern merupakan hal yang mustahil, tetapi bagi wong cilik kegiatan ini yang bekerja adalah doa. Lewat doa-doa, dupa, bunga tujuh rupa, dan seserahan lain melantarkan angan-angan semua yang diinginkan 'bakal' tercapai.

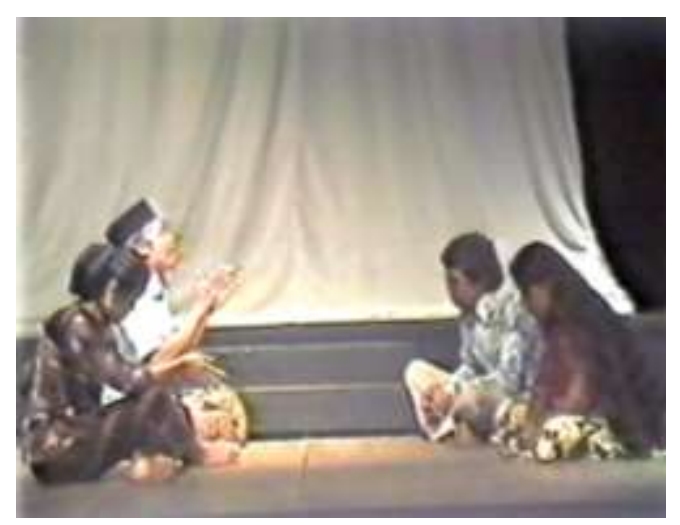

Gambar 8. Suasana umbul donga.

(Foto: repro VCD Leng, 1986)

Makam Kyai Bakal digantungkan sebagai lahan untuk mencari rejeki. Pak Rebo juga memanfaatkan moment ketika banyak tamu datang sebagai jalan untuk mengeruk keuntungan lebih banyak. Sebenarnya pemanfaatan yang dilakukan oleh Pak Rebo ini merupakan penyimpangan dari makna dasar sowan Kyai Bakal. Rapalan yang diucapkan Pak Rebo adalah hasil hafalan agar mudah untuk mengucapkan, sehingga terkadang tidak sesuai dengan permintaan tamu yang datang. Selain itu, Pak Rebo juga mendahulukan siapa saja untuk ritual sowan 
dengan memberinya upah lebih. Walaupun sebenarnya telah ada tiga kotak dana yang dipergunakan untuk mengisi kas desa, untuk karang taruna, dan untuk merawat makam. Kesakralan yang harusnya didapat dari upaya menyatuan diri dengan kosminya menjadi terganjal. Upaya yang dilakukan dibubuhi dengan hasrat pemenuhan kebutuhan diri secara berlebihan. Kondisi ini menunjukkan bahwa praktik KKN tidak hanya dilakukan oleh kalangan atas, tetapi telah merajalela hingga lini kehidupan terkecil.

Tata kehidupan di sekitar makam Kyai Bakal berbeda dengan pabrik yang disimbolkan sebagai sebuah tatanan kehidupan modern yang menutup dunia batin seseorang. Para priyayi menjalankan kehidupan berdasarkan logika dan kepuasan atas kebutuhan hidupnya. Tindakan tersebut mengakibatkan terganggunya kehidupan mapan di sekitar makam Kyai Bakal, karena kurangnya toleransi terhadap upaya penyatuan batin seseorang dengan kosmisnya. Pabrik menjadi salah satu pengganjal tintrim-nya kehidupan kosmis karena polusi suara yang dihasilkan. Walaupun pabrik sedikit banyak memberikan dampak positif pada kehidupan warga desa, tetapi upaya negosiasi yang lebih menguntungkan pabrik menjadikan ketidaknyaman. Warga Desa Bakalan menganggap bahwa kehadiran pabrik mengusik apa yang telah menjadi keselarasan kehidupan warga.

Pabrik sebagai simbol pemerintah pusat yang kurang menyelaraskan kehidupan antara manusia dengan lingkungannya. Pabrik seperti kekuasaan absolut di masa Orde Baru, mengedepankan kemajuan sesuai dengan pemikiran Juragan tanpa memikirkan budaya kosmis yang dijunjung warga Bakalan dengan makam Kyai Bakal. Seperti juga memaksa masyarakat Wonogiri untuk transmisgrasi meninggalkan lingkungan alam yang telah bertahun-tahun menjadi bagian dari hidupnya. Kehidupan pabrik dan
Juragan bukan bekerja menggunakan batin seperti yang dilakukan wong cilik, melainkan bekerja berdasarkan pemenuhan kebutuhan akan uang dan harta benda duniawi. Walaupun pada adegan kedua menunjukkan bahwa Juragan juga masih menyiapkan sesaji untuk déwa-déwanè sing nunggu. Manusia modern mengaggap ruang imajiner sebagai angan-angan seperti yang dilakukan warga terhadap makam Kyai Bakal, melantarkan doa dan mengharap berkah dari Kyai Bakal. Hampir sama dengan Juragan yang masih mempertahankan ruang imajiner tersebut dengan rutin menyiapkan sesaji.

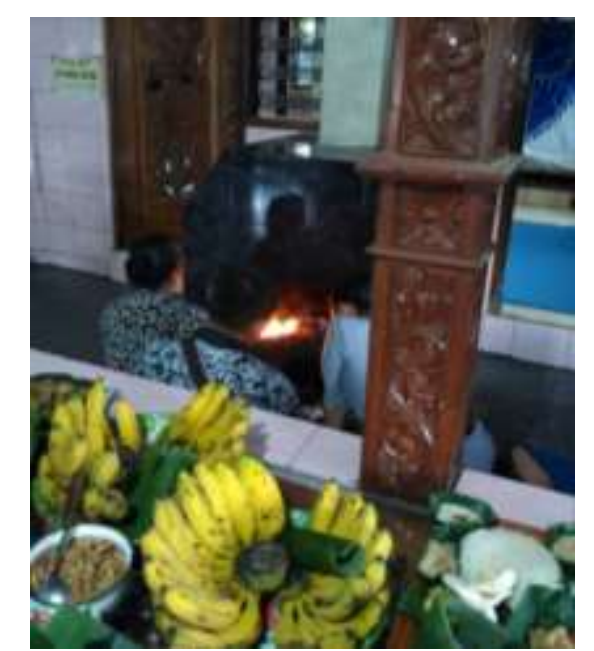

Gambar 9. Ritual meminta berkah keselamatan di Makam Kyai Bakal, Sukoharjo.

(Foto: Nissa Argarini, 2017)

Dalam pertunjukan Leng, Kenthut juga memperlihatkan perbedaan mencolok antara kehidupan warga Bakalan dan Juragan, mengenai ketenangan batin yang merupakan dampak dari kepercayaan terhadap keseimbangan kosmis. Warga Bakalan yang memegang teguh kepercayaan tentang adanya hubungan mikrokosmos dan makrokosmos menunjukkan kehidupan yang selaras, seimbang, penuh ketenangan, walaupun kehadiran pabrik mengganggu sekalipun. Wong cilik Bakalan merepresentasi dunia batin masyarakat Jawa, 
legawa dengan kehidupan yang mereka jalani. Dapat dikatakan bahwa makam Kyai Bakal sebagai wujud ekspresi wong cilik (Bongkrek). Makam Kyai Bakal tempat menaruh harapan menunjukkan ketenangan dan kenyamanan hidup selaras.

Dalam kondisi makin terdesak, sikap legawa orang Jawa akan berubah menjadi bencana. Pada takaran tertentu, perubahan sikap tersebut terkadang diekspresikan menjadi kemarahan yang ekstrim, sehingga tidak jarang melakukan tindakan-tindakan berbahaya. Seperti Bongkrek yang menjadi pengangguran, anaknya meninggal, hingga tanah warisan orang tuanya dijual oleh Yatmi. Kondisi tersebut memicu Bongkrek untuk berani melawan Juragan demi membela kehormatannya sebagai orang Jawa. Pilihan sikap Bongkrek merupakan wujud kekecawaan yang telah mencapai puncak.

Juragan, berbanding terbalik dengan Bongkrek, justru seakan mendapat teror setiap saat. Kehidupannya tidak tenang, sering halusinasi, dan merasa dirinya selalu diikuti banyak orang seolah-olah banyak orang yang berdemo atas kebijakannya untuk memperluas wilayah pabrik. Juragan memang masih melakukan praktik ritual sesaji untuk leluhur, tetapi tindakan tersebut tidak diimbangi dengan penyeimbangan terhadap perilaku toleransi dan tepa slira terhadap warga yang akan terkena dampak dari perluasan pabrik. Apabila menginginkan kehidupan yang tentram hendak menyeimbangan hubungan dengan Sang Pencipta, dengan sesama manusia, dan dengan alam sekitar yang telah memberi kehidupan. Juragan yang mengabaikan hubungan selaras dengan warga Bakalan menjadikan kehidupannya diliputi rasa waswas, khawatir, tidak tenang, hingga mengalami halusinasi berkepanjangan. Pabrik hadir sebagai wujud ekspresi dari manusia modern (priyayi) yang diwakili oleh
Juragan, sekaligus ekspresi keserakahan Juragan.

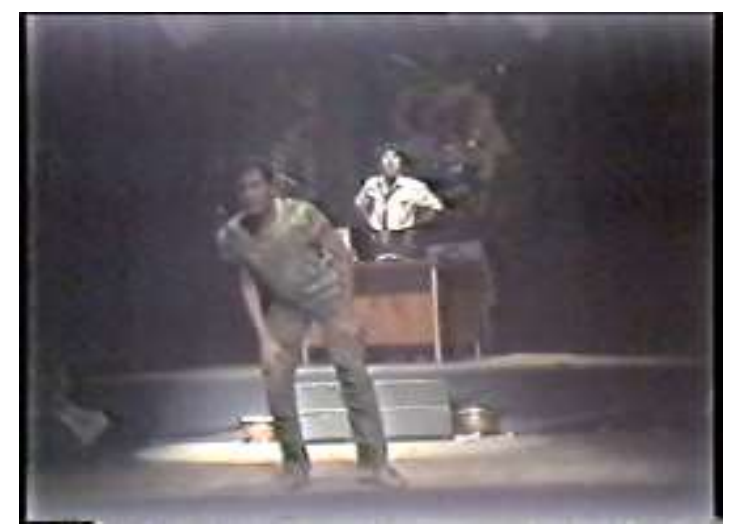

Gambar 10. Suasana saat Bedor mengecek sekitar kantor Juragan yang sedang halusinasi.

(Foto: repro VCD Leng, 1986)

Adanya kelas sosial yang saling berkaitan memberi dampak positif dan negatif. Hubungan pabrik dan makam Kyai Bakal merupakan simbol yang diutarakan oleh Kenthut untuk memperlihatkan bahwa kehidupan masyarakat -dalam hal ini diwakili oleh masyarakat Jawa-memiliki pola. Pola tersebut terajut oleh keselarasan, ketegangan, konflik, toleransi, tepa slira dan wujud keyakinan masyarakat Jawa terhadap asal dan tujuan manusia. Masyarakat Jawa meyakini bahwa ketika berusaha untuk menyelaraskan hidup dengan kosminya maka ketentraman akan mendampingi kehidupan manusia.

Kenthut adalah orang Jawa yang masih percaya bahwa kekuatan di luar dirinya sangat besar. Keseimbangan dan keselarasan haruslah dijalani demi terciptanya kehidupan yang baik. Kenthut menggambarkan anggapan orang Jawa bahwa makam sebagai tempat pengharapan. Berawal dari kegiatan bersepeda yang mempertemukannya dengan makam Kyai Balak, memancing imajinasi Kenthut untuk menciptakan sebuah harapan, sebuah bakal yang akan mengantarkan menuju keselarasan hidup. Bakal dalam bahasa Jawa berarti calon atau harapan, 
seperti yang dituliskan oleh Kenthut dalam pertunjukan Leng. Wong cilik Desa Bakalan menaruhkan harapan, doa, angan-angan pada makam Kyai Bakal dengan perantara bungabunga, dupa, raja kaya, atau sesaji yang lain.

\section{Hubungan Kenthut dan Orde Baru}

Kenthut merasakan bahwa kehidupan wong cilik tidak semulus pembangunan yang gencar dilakukan oleh pemerintah. Kehidupan pribadinya yang harus merasakan hidup susah serba kekurangan menjadikannya seorang yang legawa. Kondisi tersebut justru memacu semangatnya untuk gigih berusaha memperbaiki kehidupan (Hengki Rivai, wawancara 15 Februari 2017). Kejelian dan ketelitian Kenthut dalam melihat kehidupan membawanya dalam dunia kreativitas berkesenian. Ia melihat fenomena sosial di sekitarnya ketika rezim Orde Baru menggalakkan pembangunan yang terkadang mengorbankan rakyat kecil, kerap melakukan 'petrus' (penembak misterius), banyak kegiatan yang dicekal, bahkan kegiatan yang bersifat kebudayaan jika dianggap mengkritik kebijakan pemerintah akan diringkus.

Teater Gapit sempat merasakan betapa mencekam ketika menggelar pertunjukan dengan kepungan aparat militer, beruntung kejadian tersebut tidak berlanjut pada pencekalan ataupun penangkapan. Faktafakta sosial yang dialami Kenthut dan masyarakat di sekitarnya menjadi catatan penting bagi karya Kenthut. Brug, STUP (Suk-Suk Peng), Rol, Leng, Tuk, Dom, Reh, dan Luh (belum diselesaikan) merupakan karya Kenthut yang merefleksikan kekuasaan Orde Baru. Karya tersebut yang mengantarkan Kenthut dan Teater Gapit menuju kesuksesan gemilang, selain karena tampil menggunakan bahasa Jawa juga karena kelihaian Kenthut menyampaikan kritik kepada pemerintah dengan halus.
Kenthut hadir sebagai corong wong cilik dalam menyampaikan aspirasi tentang kondisi sosial yang miskin, terhimpit, marginal, dan serba kekurangan. Walaupun dianggap suara sumbang masa Orde Baru, Kenthut tetap pada posisinya untuk berkarya merepresentasi kehidupan sosialnya dan masyarakat di sekitar. Orde Baru memposisikan karya-karya pementasan Kenthut bersama Teater Gapit sebagai suara yang sumbang karena dari sedikit aspirasi yang diucapkan mampu mempengaruhi masyarakat lain untuk memberontak rezim otoriter saat itu. Pemberontakan akan muncul dipicu beberapa karya-karya seni yang mampu menggambarkan kondisi sosial masyarakat dapat membahayakan kedudukan Soeharto. Tidak heran pula jika seniman seperti WS. Rendra, Emha Ainun Najib, dan Wiji Tukul mendapat sorotan tajam dari pemerintah. Wiji Tukul bahkan menghilang tanpa jejak sampai sekarang. Soeharto khawatir akan adanya orang-orang yang bersuara sumbang tersebut dapat menggeser kedudukannya dari kursi nomor satu di Indonesia.

Kenthut melalui Leng ingin memperjuangkan kelasnya, kelas wong cilik. Kelas yang selalu berada tersisihkan dan terpinggirkan dari penglihatan pembangunan masa Orde Baru. Merepresentasikan masyarakat sama dengan merepresentasikan kehidupan pribadi Kenthut. Lewat Leng, Kenthut memposisikan diri sebagai Bongkrek. Bongkrek dengan tegas melawan kebijakan Juragan, Kenthut tegas menyuarakan kritik terhadap kebijakan pemerintahan Orde Baru. Kenthut mengungkapkan dengan alur yang lembut, kenyataan-kenyataan kondisi sosial masyarakat dampak dari kebijakan Orde Baru. Bongkrek bukan melawan Juragan, melainkan kebijakan yang dibuat terhadap karyawan pabrik dan warga Desa Bakalan yang dilawan. Sama halnya dengan Kenthut, bukan Soeharto yang dilawan, melainkan 
kebijakan-kebijakan yang dijalankan pemerintahan Orde Baru yang dilawannya.

Setiap zaman akan melahirkan generasinya sendiri sesuai dengan kondisi yang berkembang saat itu. Kenthut lahir sebagai generasi Orde Baru, sebuah pemerintahan yang otoriter dalam melaksanakan kebijakan-kebijakan. Kenthut sebagai anak zaman Orde Baru mampu melihat realitas sosial pada masa itu, kemudian dituangkan dalam naskah. Kenthut boleh tidak ada secara fisik, tetapi jiwa dengan semangatnya tetap ada selama naskah karyanya masih digunakan sebagai wujud kritik sosial bagi pemerintah dan bagi masyarakat. Naskah-naskah karya Kenthut tersebut akan memicu lahirnya KenthutKenthut baru dengan pemikiran yang lebih kritis.

\section{Simpulan}

Pertunjukan Leng merupakan salah satu karya Kenthut yang menggambarkan kehidupan sosial masyarakat marginal. Kehidupan yang diselimuti dengan praktik KKN (korupsi, kolusi, dan nepotisme) membuat masyarakat berlomba untuk mengeruk keuntungan dengan cara apa pun. Konflik dan kesenjangan pada masa Orde Baru menghasilkan masyarakat yang bertingkat-tingkat sesuai kelas ekonomi dan kedudukannya. Kelas sosial yang hadir dalam pertunjukan Leng yaitu wong cilik dan priyayi. Melihat kondisi sosial yang terjadi di sekitarnya, Kenthut mulai memahami masyarakat. Pemahaman tersebut menjadi inspirasi Kenthut dalam menulis karya Leng, yang kemudian mementaskannya bersama Teater Gapit.

Potret kehidupan wong cilik berada di makam Kyai Bakal sebagai tempat menaruh harapan dan angan-angan berorientasi pada sesuatu yang semu hadir pada Mbok Senik, Kecik, Pak Rebo, Janaka, dan Bongkrek. Pabrik merupakan bentuk ekspresi budaya priyayi yang selalu beriorientasi di wilayah riil dan dihidupi oleh dunia kapital. Bongkrek adalah gambaran diri Kenthut sebagai wong cilik, dan Juragan adalah gambaran dari otoriter Orde Baru. Kenthut berusaha memperjuangkan kelasnya sebagai wong cilik yang diwakili oleh perjuangan Bongkrek melawan kebijakan Juragan. Kenyataan yang harus dialami oleh masyarakat marginal berdampingan dengan pembangunan negara tetapi tidak dapat ikut merasakan. Bongkrek sebagai corong Kenthut dalam mengutarakan suara-suara rakyat yang terpinggirkan oleh modernisasi Pemerintah Orde Baru. Hal tersebut menunjukkan bahwa Leng telah merepresentasikan relitas sosial dari masyarakat di sekitar Kenthut. Juragan dan Bongkrek telah mewakili kelas-kelas sosial dalam masyarakat masa Orde Baru, hingga saat ini.

\section{Daftar Pustaka}

Bahaudin. (2015). "Mistik dan Politik: Praktik Perdukunan dalam Politik Indonesia," Jurnal Keamanan Nasional, Vol. 1, (3):365-385.

Dewanta, A. S. (1995). Kemiskinan dan Kesenjangan di Indonesia. Yogyakarta: Aditya Media.

Faruk. (2007). Belenggu Pasca-Kolonial: Hegemoni dan Resistensi dalam Sastra Indonesia. Yogyakarta: Pustaka Pelajar.

Feinstein, A. (1995). "Modern Javanese Theatre and The Politics of Culture: A Case Study of Teater Gapit," Kitlv Journals, (4):617-638.

Geertz, C. (1996). Abangan, Santri, Priyayi dalam Masyarakat Jawa, terj. Aswab Mahasin. Jakarta: Dunia Pustaka Jawa.

Johnson, D.P. (1986). Teori Sosiologi Klasik dan Modern, terj. Robert M.Z. Lawang. Jakarta: PT. Gramedia Pustaka Utama.

Kartodirdjo, S., Sudewo, A., \& Hatmosuprobo, S. (1987). Perkembangan Peradaban Priyayi. Yogyakarta: Gadjah Mada University Press. 
Kuntowijoyo. (2006). Raja, Priyayi, dan Kawula Surakarta, 1900-1915. Yogyakarta: Ombak.

Mulder, N. (2001). Mistisisme Jawa: Ideologi di Indonesia. Yogyakarta: LKiS.

Ritzer, G., \& Goodman, G.J. (2014). Teori Sosiologi: Dari Teori Sosiologi Klasik sampai Perkembangan Mutakhir Teori Sosial Postmodern. Bantul: Kreasi Wacana.

Sahid, N. (2000). "Drama TUK sebagai Simbol Perlawanan Rakyat Kecil terhadap Penguasa Orde Baru dan Simbol Runtuhnya Nilai-Nilai Budaya Jawa." Laporan Penelitian ISI Yogyakarta.

Van Peursen, C.A. (1976). Strategi Kebudayaan, (Hartoko, D., Trans.). Yogyakarta: Yayasan Kanisius.

Widaya, B. (1998). Gapit. Surakarta: STSI Press.

Wolff, J. (1981). The Social Production of Art.New York: Martin's Press.

WS, Hasanuddin. (2009). Drama: Karya dalam Dua Dimensi (Kajian, Teori, Sejarah, dan Analisis). Bandung: Angkasa.

Yudiaryani. (2015). WS Rendra dan Teater Mini Kata. Yogyakarta: Galang Pustaka. 